\title{
Üniversite ve Öğretmenlikle İlişkili Değişkenler Arasındaki İlişkiler ile Aracı ve Düzenleyici Etkilerin İncelenmesi ${ }^{1}$
}

\author{
Gizem UYUMAZ², Enver SARI ${ }^{3}$, Gözde UYUMAZ ${ }^{4}$ ve Melike Burcu YILMAZ ${ }^{5}$ \\ Öz
}

İki değişken arasındaki ilişki, yalnızca bireyin bu iki değişkene ilişkin durumuna bağlı olabileceği gibi, bu değişkenleri etkileyen farklı değişkenlerden de kaynaklanıyor olabilir. Buradan yola çıkılarak, üniversite ve öğretmenlikle ilişkili değişkenler arasındaki ilişkilerin yalnızca bu değişkenlerden mi yoksa bu değişkenlerle ilişkili farklı değişkenlerden mi kaynaklanıyor olduğunun belirlenmesi öğrenci başarısının arttırılmasına yönelik atılacak adımlar için önemlidir. Bu çalışmanın amacı üniversite ve öğretmenlikle ilişkili değişkenler arasındaki ilişkiler ile aracı ve düzenleyici etkilerin belirlenmesidir. Araştırmanın çalışma grubunu bir eğitim fakültesinin farklı bölümlerinde ve sınıf düzeylerindeki 268 öğretmen adayı oluşturmaktadır. Çalışma kapsamında veri toplama aracı olarak araştırmacılar tarafından oluşturulan anket ile Öğretmenlik Mesleğine Yönelik Tutum Ölçeği, Okula Yönelik Tutum Ölçeği, Mesleki Kayg1 Ölçeği, Üniversite Yaşamı Ölçeği ve Genel Erteleme Ölçeği kullanılmıştır. Çalışma grubundan elde edilen verilerle yapılan analizler doğrultusunda; mesleki kaygı, öğretmenlik mesleğine yönelik tutum ile üniversite yaşamı arasındaki ilişkide kısmen aracıdır. Okula yönelik tutum, öğretmenlik mesleğine yönelik tutum ile üniversite yaşamı arasındaki ilişkide kısmen aracıdır. Genel erteleme, öğretmenlik mesleğine yönelik tutum ile üniversite yaşamı arasındaki ilişkide kısmen aracıdır. Öğrencilerin öğretmenlik mesleğine yönelik tutumları ile üniversite yaşamları arasındaki ilişkide genel not ortalamasının düzenleyici etkisi vardır. Öğrencilerin öğretmenlik mesleğine yönelik tutumlan ile üniversite yaşamları arasındaki ilişkide mesleği isteyerek seçmenin düzenleyici etkisi vardır.

Anabtar Kelimeler: Aracılık etkisi, Düzenleyicilik etkisi, İlişki, Kayg1, Erteleme

Investigation of the Relationships between University and Teaching-Related Variables, and Mediating and Regulatory Effects

\begin{abstract}
The relationship between the two variables may depend not only on the individual's score for these two variables, but also on different variables that affect these variables. From this point of view, it is important for the steps to be taken to increase student achievement whether the relationships between the variables associated with university and teaching are caused only by these variables or different variables associated with these variables. The aim of this study is to determine the relations between university and teaching variables and mediator and moderator effects. The study group of the research consists of 268 prospective teachers studying in different departments of a faculty of education and at different grade levels. Within the scope of the study, the Attitude Scale for Teaching Profession, Attitude Scale for School, Occupational Anxiety Scale, University Life Scale, and General Procrastination Scale were used as a data collection tool with a questionnaire created by researchers. Professional anxiety, attitude towards school and general procrastination are partially mediated in the relationship between attitude towards teaching profession and university life. The overall grade average and choosing the profession willingly have a moderator effect on the relationship between students' attitudes towards teaching profession and university life.
\end{abstract}

Key Words: Mediation effect, Moderation effect, Relationship, Anxiety, Procrastination

\section{Atıf İçin / Please Cite As:}

Uyumaz, G., Sarı, E., Uyumaz, G. ve Yılmaz, M. B. (2020). Üniversite ve öğretmenlikle ilişkili değişkenler arasındaki ilişkiler ile aracı ve düzenleyici etkilerin incelenmesi. Manas Sosyal Araştırmalar Dergisi, 9(4), 2131-2144.

Geliş Tarihi / Received Date: 12.05.2020

Kabul Tarihi / Accepted Date: 25.06.2020

\footnotetext{
${ }^{1}$ Bu çalışma Giresun Üniversitesi’nde çalışmanın ilk yazarı yürütücülüğünde tamamlanan EĞT-BAP-A-230218-54 numaralı Bilimsel Araştırma Projesi’nden üretilmiştir.

${ }^{2}$ Dr. Öğr. Üyesi - Giresun Üniversitesi Eğitim Fakültesi, gizemuyumaz@gmail.com - ORCID: 0000-0003-0792-2289

3 Prof. Dr. - Giresun Üniversitesi Eğitim Fakültesi, enversari@hotmail.com - ORCID: 0000-0002-7623-6832

${ }^{4}$ Yüksek Lisans Öğrencisi - Kocaeli Üniversitesi Sosyal Bilimler Enstitüsü, gzdeuyumaz@gmail.com ORCID: 0000-0002-3195-569X

5 Öğretim Görevlisi - Giresun Üniversitesi Eğitim Fakültesi, melikeburcu80@hotmail.com - ORCID: 0000-0002-3580-3853
} 


\section{Giriş}

Dünyanın dört bir yanındaki eğitim politikaları, öğretmenlere giderek sosyal adalet gündemleriyle bağlantılı olarak değişimden yana olma çağrısı yapmaktadır. Bununla birlikte, bu tür bir yeterliğin öğretmen eğitiminde nasıl geliştirilebileceği konusunda netlik henüz tam olarak görülmemektedir. Öğretmenlerin meslekte yeterli olma ve sosyal adalet bağlamında değişim aracı olarak anlamlarını netleştirmek için öğretmenlik mesleğini ve kapsayıcı pedagoji teorilerini anlamak gerekmektedir. Kapsayıcı uygulama, öğretmenlerin, ailelerin, öğrencilerin, yöneticilerin işbirliğini gerektirir. Öğretmen yetiştirmek için kapsayıc1 pedagoji ve öğretmenlik mesleği teorilerini bir araya getirmenin olanaklanı tartışılmalıdır. 'Pedagoji' genellikle yalnızca sınıflarla ilgili bir uygulama olarak anlaşılırken, öğretmenlerin mesleki gereklilikleri yerine getirirken karşılaştıkları yapısal ve kültürel engellerin kaldırılması için diğer ilgili kişilerle çalışma kapasitesini geliştirme ihtiyacını vurgulamaktadır (Pantić, 2015). Bu durum öğretmenin mesleğe başlamadan önceki süreçte yani üniversite eğitimi boyunca içinde bulunduğu durumu net bir şekilde kapsamaktadır. Öğretmenlik mesleği çok boyutlu bir biçimde incelenmek istense belki de ilk karşımıza çıkacak olan kavram öğretmenlik mesleğine yönelik tutum ve inançlar olacaktır.

Tutumlar ve inançlar, öğretmenlerin düşünce yapılarında ve bunların farklılaşmasında, sınıf içi etkinliklerinde ve öğretmede önemli kavramlardır. Tutumlar, 1970'lerin başlarında öğretme ve öğretmen eğitimi araştırmalarında büyük dikkat çekerken, öğretmenliğe yönelik inanç alanyazında ancak son zamanlarda öne çıkmıştır. Genelde araştırmalar; hem tutumların hem de inançların sınıf içi eylemleri sürdürdüğünü ve öğretmenin mesleki değişim sürecini etkilediğini göstermektedir (Pajares, 1992; Richardson, 1994). Öğretmen adaylarının inanç ve tutumları, neyi ve nasıl öğrendiklerinin ve süreç içinde değişimin hedefleridir. Tutumlar ve inançlar, bir kişinin eylemlerini sürdüğu düşünülen zihinsel durumların yapısını ve içeriğini adlandıran, tanımlayan bir grup yapının alt kümesidir. Bu kümedeki diğer yapılar; kavramları, perspektifleri, algıları, yönelimleri, teorileri ve duruşları içerir. Öğretmen tutumları zaman zaman hala incelenirken, inançlar öğretmenlerin düşünme biçimlerini ve sınıf uygulamalarını incelemek için büyük bir ilgi alanı olarak ele alınmıştır (Richardson,1996). Bu durum öğretmenlik mesleğinin, meslek öncesi eğitimin ve bu süreçlerin üzerinde etki eden tüm değişkenlerin sıklıkla incelenmesini sağlamıştır. Öğretmenlerin üniversite yaşamı, mesleğe yönelik, üniversiteye yönelik tutumları, mesleki kaygı, genel erteleme davranışı gibi pek çok konuyu içermektedir. İyi bir öğretmenin yetişmesi ve mesleki kaygıdan uzak kalabilmesi için mesleki eğitimi sürecinde yaşadıklarının önemi büyüktür. Öğretmen olmak için öğrenci olanın davranış şekli öğretmen olduğunda ki davranışşeklinin bir örneği olacaktır.

Öğretmenlere yardım etmenin özü, öğretmenlik konusundaki kaygılarının araştırılmasında yatmaktadır. Bu varsayımdan yola çıarak, Poulou (2007) çalışmasında öğretmen adaylarının kaygılarını ve muhtemel yansıma konularını ögretme deneyimlerini takip etmeyi amaçlamıştır. Elli dokuz derginin analizi, öğrencilerin kişisel ve mesleki kimlikleri, öğretmenlik mesleğinin misyonu ve öğretimin duygusal boyutları ile ilgili geçmiş ve geleceğe yönelik karmaşık yapıyı ortaya çıkaran araştırmacı; öğretmenlik uygulamalarıyla gelişmeye dikkat çekmiş, öğretmen adayları için deneyim üreten deneyimlerin geliştirilmesi hakkındaki tartışmalara katkıda bulunmuştur. Deneyimin kaygıyı azalttığına dikkat çekersek öğretmen adayının eğitimi sürecinde daha fazla uygulama yapması temel bir etki yaratabilir. Çerçeve genişlediğinde kayg1 unsurlarından bir diğeri de geleceğe yönelik kaygıdır.

Öğretmenlik meslek seçimi ve eğitim sürecinde belirlenmeye çalışılan bir diğer kavram ise ertelemedir. Erteleme bireyin meslek seçimi ve mesleki başarısında etkin ve etken bir rol oynayacaktır. Erteleme, yaygın bir öz-denetimsel başarısızlık ve belirli hedeflere ulaşmak için yapılması gerekenleri yapmama ve bunun yerine uzun vadeli kazanımlarda kısa vadede daha fazla ödüllendirici faaliyetlerde bulunmaya itiraz eden bir psikolojik değişkendir (Aremu, Williams ve Adesina, 2011). Gönüllü olarak bir görevi daha sonraki bir tarihe ertelediğini söyleyen bir kişiyi bulmak, samanlıkta iğne bulmaya eşdeğerdir. Çoğu insan, özel ya da açık bir şekilde, yaşamlarında en az birkaç kez vazgeçme, bırakma ya da erteleme yaptıkları konusunda hemfikirdir. Erteleme Latince fiillerden türetilmiştir, "pro" ileriye doğru hareketi ifade eder ve "crastinus" yarına ait olmayı ifade eder (Ferrari, Johnson ve McCown, 1995). Erteleme, bir görevi son dakikaya kadar bitirmemek veya önceden belirlenen son tarihten sonra başlatmak veya bitirmek durumudur, isteğe bağl1 bir gecikme olarak tanımlanır (Rozental ve Carlbring, 2013). Erteleme, etkisiz zaman yönetimi, düşük performans seviyeleri, gecikmiş çalışma davranışları, görevden kaçınmayı sürdürme, ego tükenmesi, hız hassasiyeti değişmeleri ve olumsuz duyguları düzenleme yetersizliğine yol açan davranışsal bir model olarak da tanımlanmaktadır (Schubert ve Stewart, 2000). 
Milgram ve Marshevsky (1995), akademik erteleme sürecinin üniversite öğrencileri arasında endemik bir sorun olarak değerlendirildiğini bildirmiştir; Akademik erteleme hem davranışsal gecikme hem de kişisel rahatsızlı̆̆ içerdiği için gecikmeden dolayı yaşanan üzüntü şeklinde tanımlanır. Üniversite öğrencileri arasında erteleme sıklı̆̆ını $\% 80$ olduğu tahmin edilmektedir ve ayrıca ortaöğretim sonrası ögrenciler arasında $\% 10$ ile \%70 arasında değişen tahminlerde en sık karşılaşılan sorunlardan biri olduğu bildirilmektedir (Schubert ve Stewart, 2000, Steel ve Ferrari, 2013). Ek olarak, genel bir nüfus araştırmasından elde edilen sonuçlar, insanların yaklaşık üçte birinin ertelemeyi eğitim çabalarında büyük bir sorun olarak tanıdığını göstermektedir (Steel ve Ferrari, 2013). Amerikan üniversite öğrencilerinde akademik erteleme sıklığı \%95 olarak belirlenmiştir; Anket sonuçları ayrıca öğrencilerin \%46'sının zamanın en az yarısında akademik görevlerde erteleme yaptıklarını bildirmiştir (Balkis ve Duru, 2007). Görünen şudur ki öğrenciler akademik görevleri erteler. Bunun yerine düşük performansa ve sonuçta akademik başarılarını olumsuz yönde etkileyen olumsuz duygusal tepkilere yol açan verimsiz etkinliklere odaklanırlar (Schubert ve Stewart, 2000).

Öğretmenlik mesleğini seçen ve bu konuda ilgili fakültelerde eğitim alan öğrencilerin tutum ve davranışlarının çeşitli değişkenler açısından incelenmesi gerekmektedir. Özellikle öğretmen adaylarının üniversite yaşamında kendi yeterliliklerini anlama, öğretmenliğe yönelik tutumlarının oluşması, mesleğe yönelik kaygı düzeyleri, erteleme davranışları başlıca olanlarıdır. Yapılan araştırmalar (Finney ve Schraw, 2003; Tümerdem, 2007; Doğan ve Çoban, 2009; DeVaney, 2010; Hussain, 2011; Kalemoğlu, Erbaş ve Ünlü, 2014; Kutlu, Gökdere ve Çakır, 2015; Serin, Güneş ve Değirmenci, 2015; Dadandı, Kalyon ve Yazıc1, 2016) göstermektedir ki eğitim fakültelerini seçen öğrencilerinin mesleğe yönelik tutumları olumlu yönde, geleceğe yönelik kaygıları orta düzeydedir, genel akademik erteleme düzeyleri ise temel beceri eğitimi ile birlikte düşmektedir. Sözkonusu değişkenlerin incelenmesi mesleği gelişimi ve eğitim fakültelerinde programların düzenlenmesi açısından önemlidir.

Söz konusu çalışmaların pek çoğunda değişkenler arasındaki ilişkiler yalnızca korelasyon ile belirlenmiştir. Eğitimde ve psikolojide iki değişken arasındaki ilişki, yalnızca bireyin bu iki değişkene ilişkin durumuna bağlı olabileceği gibi, bu değişkenleri etkileyen farklı değişkenlerden de kaynaklanıyor olabilir. Üniversite ve öğretmenlikle ilişkili değişkenler arasındaki ilişkiler için de bu durum söz konusudur. Buradan yola çıkılarak, üniversite ve ögretmenlikle ilişkili değişkenler arasındaki ilişkinin yalnızca bu değişkenlerden mi yoksa bu değiş̧kenlerle ilişkili farklı değişkenlerden mi kaynaklanıyor olduğunun belirlenmesi gereği ortaya çıkmaktadır. Ancak bu belirlemeler yapıldığında öğrenci başarısının arttırılmasına yönelik yapılacak çalışmalar istenen sonuçları verebilir.

\section{Amaç}

Bu çalışmanın amacı üniversite ve öğretmenlikle ilişkili değişkenler arasındaki ilişkiler ile aracı ve düzenleyici etkilerin belirlenmesidir. Bu amaç doğrultusunda yanıt aranana sorular:

1. Öğrencilerin okula yönelik tutumları, öğretmenlik mesleğine yönelik tutumları, mesleki kaygıları, üniversite yaşamları ve genel erteleme davranışları arasındaki ilişkiler nasıldır?

2. Öğrencilerin öğretmenlik mesleğine yönelik tutumları ile üniversite yaşamları arasındaki ilişkide

a. Mesleki kaygilarının,

b. Okula yönelik tutumlarının ve

c. Genel erteleme davranışlarının aracı etkisi var mıdır?

3. Öğrencilerin öğretmenlik mesleğine yönelik tutumlanı ile üniversite yaşamlanı arasındaki ilişkide

a. Genel not ortalaması ve

b. Mesleği isteyerek seçmenin düzenleyici etkisi var mıdır?

\section{Yöntem}

\section{Araştırma Modeli}

$\mathrm{Bu}$ çalışma üniversite ve öğretmenlikle ilişkili değişkenler arasındaki ilişkiler ile aracı ve düzenleyici etkilerin belirlenmesini amaçlayan korelasyonel bir araştırmadır. 


\section{Çalışma Grubu}

Çalışma grubu Giresun Üniversitesi Eğitim Fakültesinin farklı bölümlerinde ve sınıf düzeylerindeki katılımcılar oluşturmaktadır. Katılımcılar 199'u (\%74.3) kadın, 69’u (\%25.7) erkek olmak üzere 268 öğretmen adayıdır. 199’u (\%74.3) üçüncü sınıfta, 67'si (\%25) dördüncü sınıfta öğrenim görmektedir. Katılımcıların 218'i (\%81.3) öğretmenlik mesleğini isteyerek seçtiğini, 47’si (\%17.5) ise öğretmenlik mesleğini isteyerek seçmediğini belirtmiştir. Katıllımclların çoğunluğunun $132(\% 49.3)$ anne eğitim düzeyi ilkokuldur, baba eğitim düzeyleri ise 78’i (\%29.1) ilkokul, 63’ü (\%23.5) ortaokul, 73’ü (\%27.2) lise ve 45’i (\%16.8) üniversitedir. Ailesinin yaşadığı yere göre dağılım; 54’ü (\%20.1) köy, 91’i (\%34) ilçe, 58’i (\%21.6) il ve 64’ü (\%23.9) büyükşehirdir.

\section{Veri Toplama Araçları}

Çalışma kapsamında araştırmacılar tarafından oluşturulan anket ile Öğretmenlik Mesleğine Yönelik Tutum Ölçeği, Okula Yönelik Tutum Ölçeği, Mesleki Kaygı Ölçeği, Üniversite Yaşamı Ölçeği ve Genel Erteleme Ölçeği kullanılmıştır.

Öğretmenlik Mesleğine Yönelik Tutum Ölçeği Üstüner (2006) tarafindan geliştirilmiştir. Ölçek beşli Likert tipindedir ve 34 maddeden oluşmaktadır. Geliştirme çalışmasında faktör yük değerlerinin 0.41-0.74 arasında değiştiği, tek faktörlü yapının varyansın \%30'unu açıkladı̆̆ı, madde toplam korelasyon değerlerinin 0.42-0.74 arasında değiştiği, ölçüt geçerliliğinin 0.89, test tekrar test güvenirlik katsayısının 0.72 , Cronbach Alfa katsayısının 0.93 olduğu bulunmuştur.

Okula Yönelik Tutum Ölçeği Gülleroğlu (2008) tarafindan geliştirilmiştir. Ölçek beşli Likert tipindedir ve 3 faktör (okulu sevme, okulu benimseme ve okula ait olma hissini taşıma), 33 maddeden oluşmaktadır. Geliştirme çalşsmasında madde-toplam test korelasyonları oldukça yüksek bulunmuştur. Faktör analizi sonucunda birinci faktörün toplam varyansın \%37'sini, üç faktörün birlikte toplam varyansın \%48'ini açıkladığ1 raporlanmıştır. Özdeğerler sırasıyla 12.046, 1.952 ve 1.752 'dir. Elde edilen Cronbach Alfa iç tutarlılık katsayısı 33 maddelik ölçeğin 0.94 , alt boyutların sırası ile $0.85,0.84,0.85$ 'tir.

Mesleki Kayg̨ Ölçeği Cabı ve Yalçınalp (2013) tarafindan geliştirilmiştir. 45 maddelik 8 faktörlü ölçeğin tüm faktörleri toplam varyansın \%65.724'ünü açıklamaktadır. Beşli Likert tipindeki ölçekte, faktör yükleri 0.497-0.899, Cronbach Alfa katsayıları 0.67-0.95 arasında değişmektedir. Faktörler: görev merkezli, ekonomik/sosyal merkezli, öğrenci/iletişim merkezli, meslektaş ve veli merkezli, kişisel gelişim merkezli, atanma merkezli, uyum merkezli ve okul yönetimi merkezli kayg1.

Üniversite Yaşamı Ölçĕğ (ÜYÖ), Aladağ, Kağnıcı, Tuna ve Tezer (2003) tarafindan geliştirilmiştir. Yedili Likert tipindeki ölçek 48 maddeden oluşmaktadır. Altı alt boyuttan oluşan ölçekteki alt boyutlar: üniversite ortamına uyum, duygusal uyum, kişisel uyum, karşı cinsle ilişkiler, akademik uyum ve sosyal uyum. Cronbach Alpha katsayıları 0.59-91 arasında değişmektedir.

Genel Erteleme Ölçeği Ölçeği Çakıcı (2003) tarafindan geliştirilmiştir. 18 maddeden oluşan ölçek beşli Likert tipindedir. Ölçeğin Cronbach Alfa güvenirlik katsayllar10.85-0.91 arasında değişmektedir. Ölçeğin test tekrar test güvenirlik katsayısı ilk faktör için 0.79 , ikinci faktör için ise 0.89 olarak hesaplanmıştır.

Bu çalışma kapsamında ölçme araçlarının 268 öğretmen adaylarına uygulanması ile toplanan verilere ilişkin geçerlik kanıtları doğrulayıcı faktör analiziyle, güvenirlik kanıtları ise Cronbach alfa iç tutarlılık katsayıları ile belirlenmiştir. İlgili sonuçlar Tablo 1'de sunulmuştur.

Tablo 1. Geçerlik. ve Güvenirlik. Kantlar

\begin{tabular}{|c|c|c|c|c|c|c|}
\hline & Cronbach Alfa & $\chi^{2} / \mathrm{sd}$ & RMSEA & $S R M R$ & $C F I$ & $\begin{array}{c}\text { Standardize } \\
\text { Faktör Yükleri }\end{array}$ \\
\hline$O M Y T$ & 0.955 & 4.799 & 0.120 & 0.074 & 0.95 & $0.39-0.81$ \\
\hline$O Y T$ & 0.940 & 3.619 & 0.099 & 0.074 & 0.95 & $0.33-0.81$ \\
\hline$M K$ & 0.960 & 2.756 & 0.081 & 0.087 & 0.96 & $0.40-0.91$ \\
\hline$G E O$ & 0.928 & 4.786 & 0.120 & 0.077 & 0.95 & $0.43-0.86$ \\
\hline$U \boldsymbol{Y}$ & 0.884 & 2.070 & 0.063 & 0.079 & 0.89 & $0.15-0.80$ \\
\hline
\end{tabular}

Tablo 1 incelendiğinde, $\chi^{2} /$ sd oranları mükemmel $(<3)$ ve iyi $(<5)$ uyumu göstermektedir (Kline, 2005). RMSEA OMYT ve GEO için zayıf uyum kriterinin $(\leq 0.10)$ altında, diğgerleri için kabul edilebilirdir (Tabachnick ve Fidell, 2001). SRMR; MK için $\leq 0.10$ vasat uyuma (Kline, 2005), diğer ölçekler için $\leq 0.08$ iyi uyuma (Brown, 2006; akt: Çokluk, Şekercioğlu ve Büyüköztürk, 2010) karşıllk gelmektedir. CFI; >0.90 
iyi $>0.95$ mükemmel uyumu gösterir (Tabachnick ve Fidell, 2001). Analizler sonucunda elde edilen geçerlik kanıtları (uyum indeksi değerleri, standartlaştırılmış yükler, açıklanan varyans, hata varyansı ve $t$ değerleri) birlikte ele alındığında incelenen modellerin uyumlu olduğu görülmektedir. Her bir ölçme aracının öğretmen adaylara uygulanmasıyla elde edilen puanlara ilişkin Cronbach alfa iç tutarlılık katsayıları incelendiğinde, güvenirlik derecelerinin yüksek (Özdamar, 2004) olduğu görülmektedir.

\section{Verilerin Analizi}

Toplanan verilerdeki kayıp değerler, uç değerler, toplam puanların normalliği, çoklu doğrusal bağlantı problemi incelenmiştir. Korelasyon katsayısı yorumlanırken mutlak değer olarak 0.00-0.30 arası düşük, 0.30-0.70 arası orta, 0.70-1.00 arası yüksek düzeyde ilişki (Büyüköztürk, 2014) olarak yorumlanmıştır.

Her bir ölçme aracından alınan puanlar için doğrulayıcı faktör analizi yapılarak ölçme modeli test edilmiştir. Her bir ölçme aracı için ölçme modelinin test edilmesi ile elde edilen yol diyagramları incelenmiş, her ölçek için tüm maddelerin t değerleri istatistiksel olarak anlamlıdır. Modelde yer alan her bir ölçme aracı için ölçme modeli test edildiğinden analizin bu aşamasından sonra maddeler ile değil her bir alt boyuttan alınan toplam puanlarla işlemler yapilmıştır.

Aracı ve düzenleyici değişken modelde yer alan üçüncü bir değişkendir (MacKinnon, 2011). Arac1 değişken iki değişken arasındaki ilişkiyi açılarken, düzenleyici değişken bu ilişkiyi değiştirir (Avcı Vardar, 2019). Aracılıkta; bağımsız değişken aracı değişkeni etkiler, aracı değişken ise bağımlı değişkeni etkiler. Düzenleyicilikte ise bağımlı ve bağımsız değişken arasındaki ilişkinin gücü veya yönü etkilenir. Aracılık modeli, dolaylı ve doğrudan etkileri ortaya koymayı amaçlar. Özellikle dolaylı etkileri de ortaya koyabilmesi nedeniyle davranış bilimlerinde sık kullanılan bir istatistiksel tekniktir. Bu istatistiksel teknik sayesinde, bağımsız değişkenin bağımlı değişken üzerindeki etkisi incelenebildiği gibi, aracı değişkenlerin üretkenlik etkisi de incelenebilir (Baron ve Kenny, 1986). Bu çalışmada aracılık etkisinin test edilmesinde yol analizi, düzenleyicilik etkisinin test edilmesinde çoklu doğrusal regresyon analizi kullanılmıştır.

\section{Bulgular}

Öğrencilerin öğretmenlik mesleğine yönelik tutumları (OMYT), okula yönelik tutumları (OYT), mesleki kaygıları (MK), genel erteleme davranışları (GEO) ve üniversite yaşamları (UY) arasındaki ilişkilerin belirlenerek Tablo 1'de sunulmuştur.

Tablo 2. Değiskenler Arasindaki İliskiler

\begin{tabular}{|c|c|c|c|c|c|}
\hline & $O M Y T$ & $O Y T$ & MK & $G E O$ & $U Y$ \\
\hline$O M Y T$ & 1,000 & & & & \\
\hline$O Y T$ & ,381 & 1,000 & & & \\
\hline$M K$ &,- 314 &,- 232 & 1,000 & & \\
\hline$G E O$ &,- 346 &,- 231 & ,252 & 1,000 & \\
\hline$U Y$ & ,389 & ,363 &,- 363 &,- 389 & 1,000 \\
\hline
\end{tabular}

Pearson momentler çarpımı korelasyon katsayıları, $\mathrm{p}=0.000, \mathrm{~N}=268$

Tablo 2 incelendiğinde, ögretmen adaylarının OMYT ile OYT ve UY arasında pozitif yönde orta düzeyde, OMYT ile MK ve GEO davranışları arasında negatif yönde orta düzeyde istatistiksel olarak anlamlı bir ilişki vardır. Öğretmen adaylarının OYT ile UY arasında pozitif yönde orta düzeyde, OYT ile MK ve GEO arasında negatif yönde düşük düzeyde istatistiksel olarak anlamlı bir ilişki vardır. Öğretmen adaylarının MK ile GEO arasında pozitif yönde düşük düzeyde, UY arasında ise negatif yönde orta düzeyde istatistiksel olarak anlamlı bir ilişki vardır. Öğretmen adaylarının GEO ile UY arasında negatif yönde orta düzeyde istatistiksel olarak anlamlı bir ilişki vardır.

\section{Öğrencilerin Öğretmenlik Mesleğine Yönelik Tutumları İle Üniversite Yaşamları Arasındaki İlişkide Mesleki Kaygılarının Aracılık Etkisi}

Önceki bölümde ayrı ayrı test edilen ölçme modelleri tek bir modelde ele alınmış ve gizil değişkenler arasındaki ilişkiler belirlenmiştir. Ölçme modellerinin eşzamanll kontrolü ve modelde yer alacak değişkenler arasındaki ilişkilerin belirlenmesi amacıyla yapılan yol analizi sonucunda OMYT ile UY arasındaki korelasyon katsayıs 0.40 , OMYT ile MK arasındaki korelasyon katsayıs -0.33 , UY ile MK arasındaki korelasyon katsayısı -0.31 olarak hesaplanmıştır. Bu model ile OMYT değişkeninin, UY ve MK 
değişkenleri ile ilişkili olduğuna dair kanıt elde edilmiştir. Analizin ilerleyen aşamasında OMYT ile UY arasındaki 0.40 düzeyindeki bu ilişkiye MK değişkenince aracılık edilip edilmediği belirlenmiştir.

Öncelikle model aracı değişken modele eklenmeden test edilmiştir. Şekil 1'de modele ilişkin standardize edilmiş değerlerin verildiği yol diyagramı sunulmuştur. Daha sonra aracı değişken modele eklenerek model tekrar test edilmiştir. Şekil 2'de aracı değişken olan modele ilişkin yol diyagramı sunulmuştur.

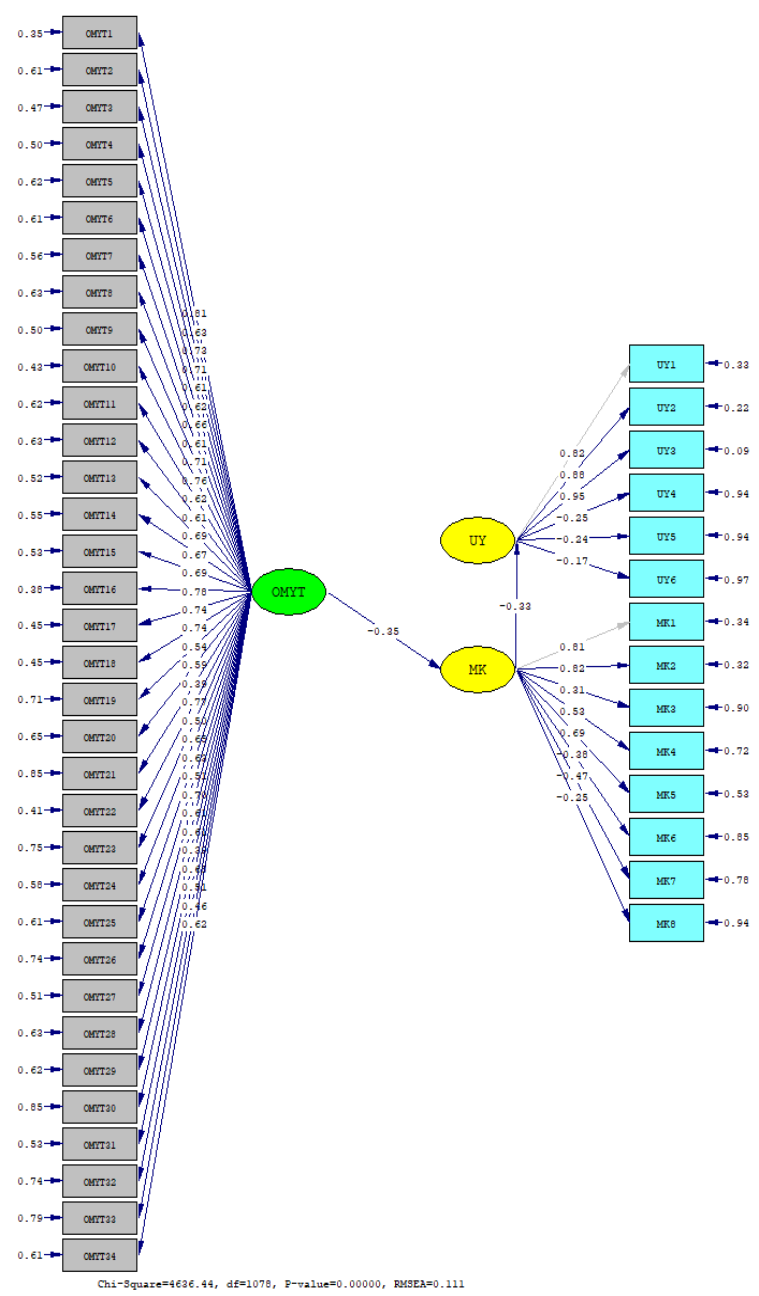

Şekil 1. Aracı Değğskeen Eklenmeden Yol Diyagramı

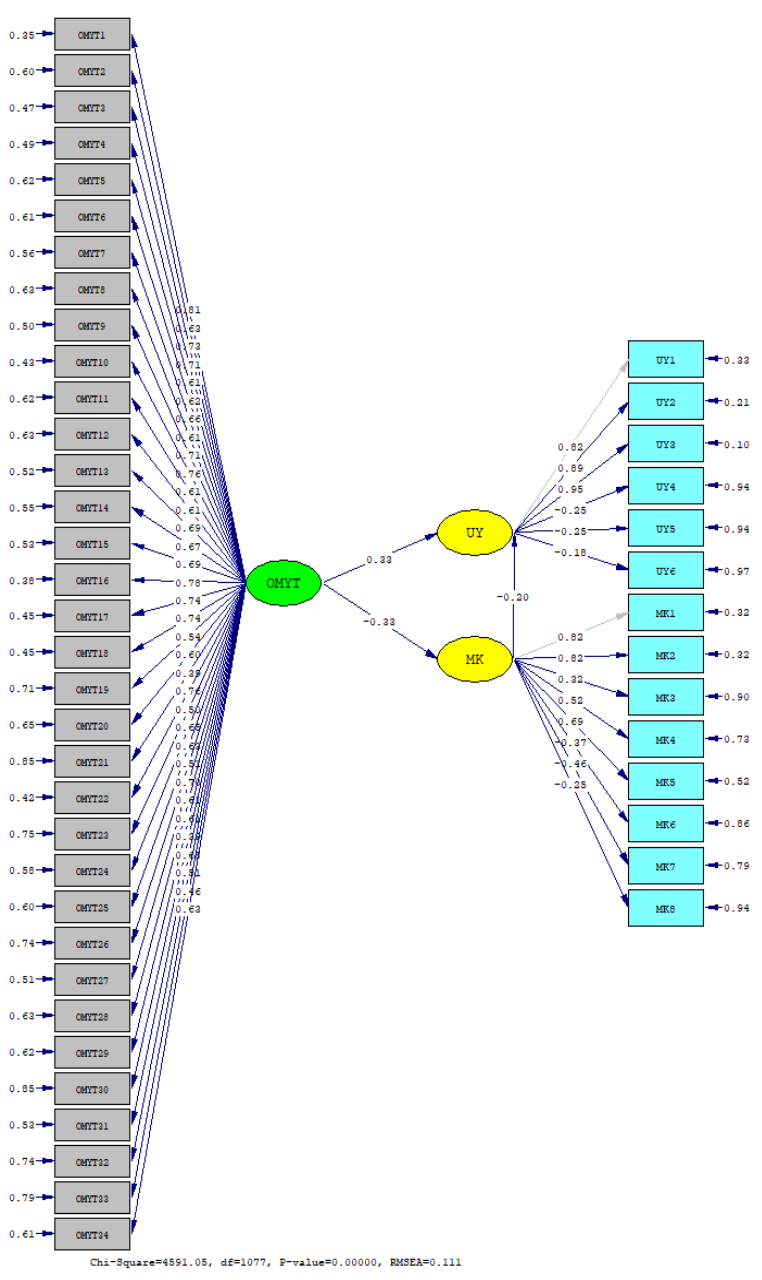

Şekil 2. Aracı Değişkeen Eklendikten Sonra Yol Diyagramı

Yapılan aracılık testi sonuçları incelendiğinde, modelde öğretmenlik mesleğine yönelik tutumdan üniversite yaşamına giden yolun değerin 0.40 'dan düşük olduğu (0.33) görülmektedir. Yol istatistiksel olarak anlamlıdır ancak değerde azalma mevcuttur. İlişkinin miktarında düşüşs olması kısmen aracılığın göstergesidir. İki değişken arasındaki ilişkinin bir başka değişkeni şart koştuğu görülmektedir. Bir başka deyişle OMYT ile UY arasındaki ilişki MK değişkenini şart koşmaktadır. MK, OMYT ile UY arasındaki ilişkide kısmen aracıdır.

Kurulan aracilık modeline ilişkin uyum indeksi incelendiğinde; $\chi^{2} / \mathrm{sd}(4.26)<5$ iyi uyumu göstermektedir (Kline, 2005). RMSEA $=0.11$ zayıf uyum kriterinin $(\leq 0.10)$ altındadır (Tabachnick ve Fidell, 2001). SRMR $=0.12$ vasat uyuma karşllı gelmektedir (Kline, 2005). IFI $=0.93$, NNFI $=0.92$ ve CFI $=0.93$ indekslerin $>0.90$ iyi uyumu gösterir (Tabachnick ve Fidell, 2001). Analizler sonucunda elde edilen geçerlik kanıtları (uyum indeksi değerleri, standartlaştırılmış yükler, açıklanan varyans, hata varyansı ve t değerleri) birlikte ele alındığında incelenen modelin uyumlu olduğu görülmektedir.

\section{Öğrencilerin öğretmenlik mesleğine yönelik tutumları ile üniversite yaşamları arasındaki ilişkide Okula yönelik tutumlarının aracılık etkisi}

Ölçme modellerinin eşzamanlı kontrolü ve modelde yer alacak değişkenler arasındaki ilişkilerin belirlenmesi amacıyla yapılan yol analizi sonucunda OMYT değişkeninin, UY ve OYT değişkenleri ile 
ilişskili olduğuna dair kanıt elde edilmiştir. OMYT ile UY arasındaki 0.40 düzeyindeki ilişkiye OYT değişkenince aracılık edilip edilmediği belirlenmiştir.

Şekil 3'de aracı değişken modele eklenmeden önceki, Şekil 4'de aracı değişken olan modele ilişkin standardize edilmiş değerleri içeren yol diyagramı sunulmuştur.

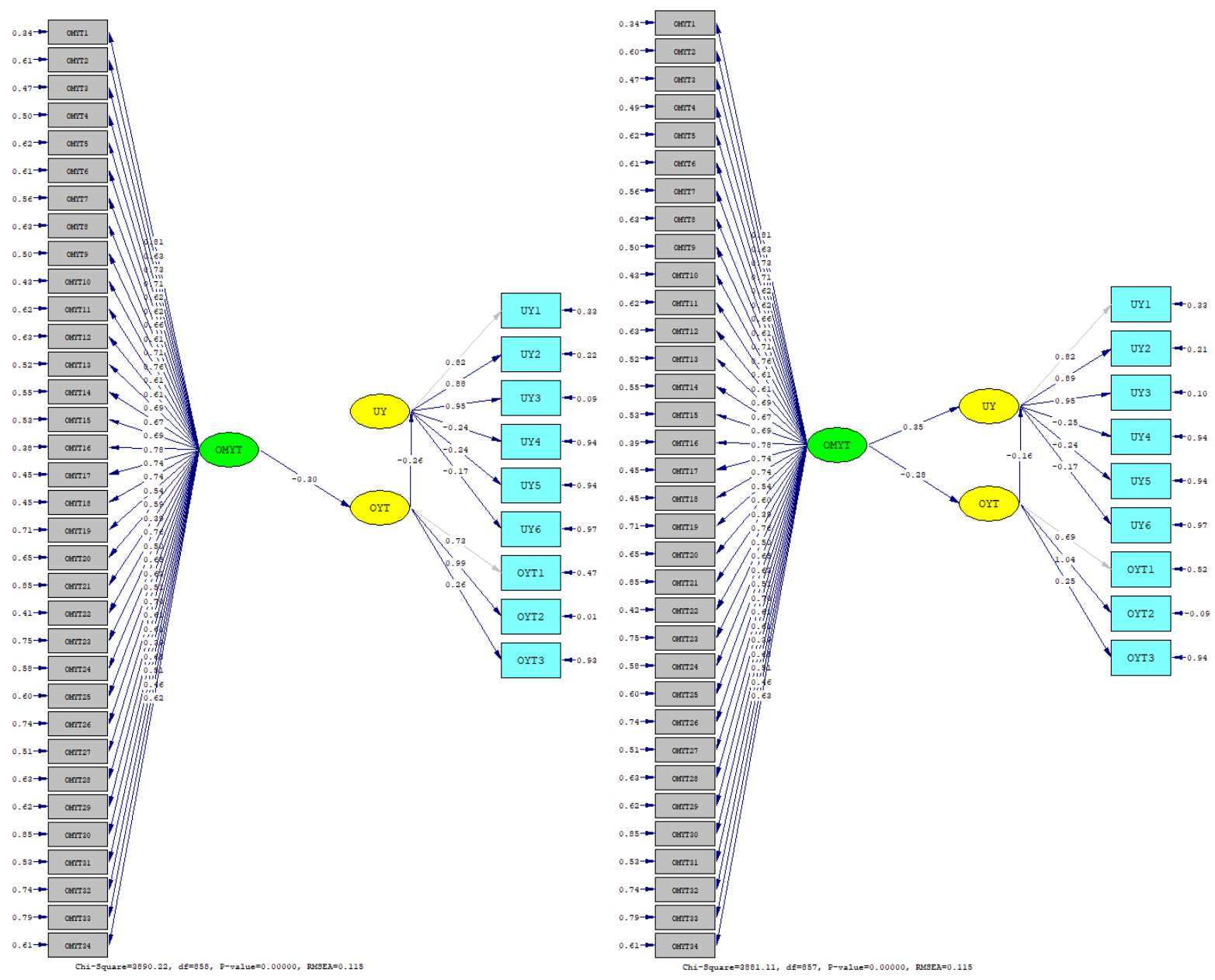

Şekil 3. Aracı Değişken Eklenmeden Yol Diyagramı

Şekil 4. Aracı Değişkeen Eklendikten Sonra Yol Dijagramı

Yapılan aracılık testi sonuçları incelendiğinde, modelde öğretmenlik mesleğine yönelik tutumdan üniversite yaşamına giden yolun değerin 0.40 'dan düşük olduğu (0.35) görülmektedir. Yol istatistiksel olarak anlamlıdır ancak değerde azalma mevcuttur. İlişkinin miktarında düşüş olması kısmen aracıllı̆ın göstergesidir. OMYT ile UY arasındaki ilişki OYT değişkenini şart koşmaktadır. OYT, OMYT ile UY arasındaki ilişkide kısmen aracıdır.

Kurulan aracılık modeline ilişkin uyum indeksi değerleri incelendiğinde; $\chi^{2} /$ sd (4.53) iyi uyumu gösterir (Kline, 2005). RMSEA $=0.11$ zayıf uyum kriterinin $(\leq 0.10)$ altındadır (Tabachnick ve Fidell, 2001). SRMR $=0.11$ vasat uyuma karşlltk gelmektedir (Kline, 2005). IFI $=0.93$, NNFI $=0.93$ ve CFI $=0.93$ indeksleri iyi uyuma karşlık gelir (Tabachnick ve Fidell, 2001). Analizler sonucunda elde edilen geçerlik kanıtları incelenen modelin uyumlu olduğu görülmektedir.

\section{Öğrencilerin öğretmenlik mesleğine yönelik tutumları ile üniversite yaşamları arasındaki ilişkide Genel erteleme davranışlarının aracılık etkisi}

Ölçme modellerinin eşzamanlı kontrolü ve modelde yer alacak değişkenler arasındaki ilişkilerin belirlenmesi amacıyla yol analizi ile öğretmenlik mesleğine yönelik tutum değişkeninin, üniversite yaşamı ve genel erteleme değişkenleri ile ilişskili olduğuna dair kanıt elde edilmiştir. Analizin ilerleyen aşamasında öğretmenlik mesleğine yönelik tutum ile üniversite yaşamı arasındaki 0.40 düzeyindeki bu ilişkinin genel erteleme değişkenince aracılık edilip edilmediği belirlenmiştir. 
Şekil 5'de aracı değişken modele eklenmeden önceki, Şekil 6'da aracı değişken olan modele ilişkin standardize edilmiş değerleri içeren yol diyagramı sunulmuştur.
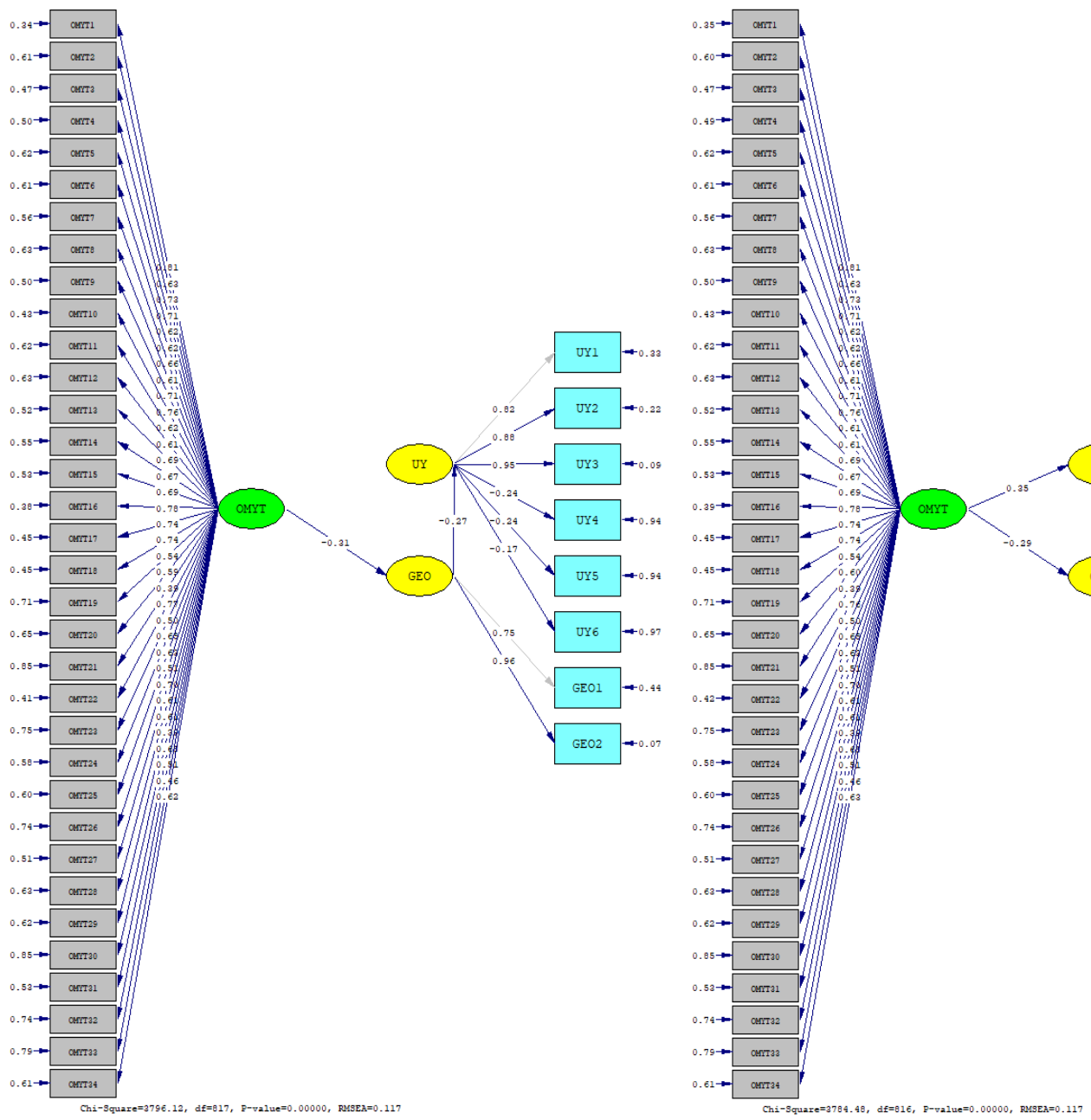

Şekil 5. Aracı Değģskeen Eklenmeden Yol Dijagramı

Şekil 6. Aracı Değğskeen Eklendikten Sonra Yol Dijagramı

Yapılan aracılık testi sonuçları incelendiğinde, modelde öğretmenlik mesleğine yönelik tutumdan üniversite yaşamına giden yolun değerin 0.40 'dan düşük olduğu (0.35) görülmektedir. Yol istatistiksel olarak anlamlıdır ancak değerde azalma mevcuttur. GEO, OMYT ile UY arasındaki ilişkide kısmen aracıdır. Kurulan aracılık modeline ilişkin uyum indeksi değerleri incelendiğinde; $\chi^{2} /$ sd oranının (4.64) $\leq 5$ olması iyi uyumu gösterir (Kline, 2005). RMSEA $=0.12$ zayıf uyum kriterinin $(\leq 0.10)$ altındadır (Tabachnick ve Fidell, 2001). SRMR $=0.10$ vasat uyuma karş1lik gelmektedir (Kline, 2005). IFI=0.93, NNFI $=0.93$ ve CFI=0.93 indeksleri iyi uyuma karşıllı gelir (Tabachnick ve Fidell, 2001). Analizler sonucunda elde edilen geçerlik kanıtları modelin uyumlu olduğu göstermektedir.

\section{Öğrencilerin öğretmenlik mesleğine yönelik tutumları ile üniversite yaşamları arasındaki ilişkide mesleği isteyerek seçmenin düzenleyici etkisi}

Öğrencilerin OMYT ile UY arasındaki ilişkide mesleği isteyerek seçmenin düzenleyici etkisi olup olmadığını belirlemek amacıyla yapılan analiz sonuçları Tablo 3 ve Tablo 4'de sunulmuştur.

Tablo 3. Model Özeti ve ANOV A Sonuclar

\begin{tabular}{lcccccc}
\hline & $\begin{array}{c}\text { Kareler } \\
\text { toplami }\end{array}$ & $\boldsymbol{s d}$ & $\boldsymbol{R}$ & $\boldsymbol{R}^{2}$ & $\boldsymbol{F}$ & $\boldsymbol{p}$ \\
\hline Regresyon & 30296,047 & 3 &, 422 &, 178 & 18,898 &, 000 \\
Arttk & 139474,064 & 261 & & & & \\
\hline Toplam & 169770,111 & 264 & & & & \\
\hline
\end{tabular}


Yordayıcı değişkenler ile UY arasındaki ilişki orta düzeydedir (0.422). Bireylerin OMYT, mesleği isteyerek seçme ve OMYT ile mesleği isteyerek seçmenin etkileşimi puanları, UY puanlarına ilişsin varyansın \%17.8'ini açıklamaktadır. kurulan model anlamlıdır. Analize dahil edilen bağımsız değişkenlerin, üniversite yaşamının anlamlı yordayıcılarıdır $\left(\mathrm{F}_{(3,261)}=18.898, \mathrm{p}<0.01\right)$.

Tablo 4. Regresyon Modeli

\begin{tabular}{lccccccc}
\hline Değiģken & Katsayı & Std. Hata & $\beta$ & $\boldsymbol{t}$ & $\boldsymbol{p}$ & $\boldsymbol{r}_{\text {ikili }}$ & $\boldsymbol{r}_{\text {ksmi }}$ \\
\hline Sabit & 185,996 & 1,752 & & 106,140 &, 000 & & \\
Zpuanı (OMYT) & 13,488 & 1,981 &, 473 & 6,807 &, 000 &, 390 &, 388 \\
Zpuanı (mesleği_isteyerek) &, 046 & 2,341 &, 002 &, 020 &, 984 &,- 142 &, 001 \\
Etkileşim & $-4,220$ & 1,939 &,- 182 & $-2,177$ &, 030 &, 030 &,- 134 \\
\hline
\end{tabular}

Tablo 4 incelendiğinde UY ile OMYT arasında orta düzeyde pozitif ( $\left.\mathrm{r}_{\mathrm{ikilili}}=0.390\right)$ bir ilişskinin olduğu, analize dahil edilen diğer bağımsız değişkenler kontrol edildiğinde bu ilişkinin değişmediği $\left(\mathrm{r}_{\mathrm{ksmmi}}=0.388\right)$ görülmektedir. Mesleği isteyerek seçme ve UY arasında ise düşük düzeyde negatif $\left(\mathrm{r}_{\mathrm{ikili}}=-0.142\right)$ bir ilişkinin olduğu ve diğer değişkenler kontrol edildiğinde bu ilişkinin ortadan kalktığı $\left(\mathrm{r}_{\text {kssmi }}=0.001\right)$ görülmektedir. UY ile etkileşim puanı arasında çok düşük düzeyde pozitif $\left(\mathrm{r}_{\mathrm{i} k \mathrm{kili}}=0.030\right)$ bir ilişsinin olduğu, diğer değiş̧kenler kontrol edildiğinde ilişkinin miktarının yükseldiği $\left(\mathrm{r}_{\mathrm{kssmi}}=-0.134\right)$ görülmektedir.

Mesleği isteyerek seçmenin, üniversite yaşamı üzerinde tek başına anlamlı bir etkisi yoktur. Ancak öğretmenlik mesleğine yönelik tutum ile mesleği isteyerek seçmenin etkileşimi üniversite yaşamının anlamlı yordayıcısıdır. Bu durum mesleği isteyerek seçmenin, üniversite yaşamı ile öğretmenlik mesleğine yönelik tutum arasındaki ilişkide düzenleyici değişken olduğunu göstermektedir. Bu duruma ek kanıt elde etmek amacıyla mesleği isteyerek seçme durumuna göre oluşan alt gruplarda ilişkiler incelenmiştir. Mesleği isteyerek seçenlerin öğretmenlik mesleğine yönelik tutumları ile üniversite yaşamları arasında pozitif yönde orta düzeyde istatistiksel olarak anlamlı bir ilişki vardır $(\mathrm{r}=0.426, \mathrm{p}=0.000, \mathrm{~N}=218)$. Mesleği isteyerek seçmeyenlerin öğretmenlik mesleğine yönelik tutumları ile üniversite yaşamları arasında istatistiksel olarak anlamlı bir ilişki yoktur ( $\mathrm{r}=0.192, \mathrm{p}=0.195, \mathrm{~N}=47)$.

\section{Öğrencilerin öğretmenlik mesleğine yönelik tutumları ile üniversite yaşamları arasındaki ilişkide genel not ortalamasının düzenleyici etkisi}

Öğrencilerin OMYT ile UY arasındaki ilişkide genel not ortalamasının düzenleyici etkisi olup olmadığını belirlemek amacıyla yapılan analiz sonuçları Tablo 5 ve Tablo 6'da sunulmuştur.

Tablo 5. Model Özeti ve ANOVA Sonuclar

\begin{tabular}{lcccccc}
\hline & $\begin{array}{c}\text { Kareler } \\
\text { toplami }\end{array}$ & $\boldsymbol{s d}$ & $\boldsymbol{R}$ & $\boldsymbol{R}^{2}$ & $\boldsymbol{F}$ & $\boldsymbol{p}$ \\
\hline Regresyon & 29124,682 & 3 &, 424 &, 179 & 18,301 &, 000 \\
Art1k & 133150,115 & 251 & & & & \\
\hline Toplam & 162274,797 & 254 & & & & \\
\hline
\end{tabular}

Yordayıcı değişkenler ile UY arasındaki ilişki orta düzeydedir. Bireylerin OMYT ve OMYT ile genel not ortalamalarının etkileşimi, UY puanlarına ilişkin varyansın \%17.9'unu açıklamaktadır. Kurulan model anlamlıdır. Analize dahil edilen bağımsız değişkenlerin, üniversite yaşamının anlamlı yordayıcıları olduğu bulunmuştur $\left(\mathrm{F}_{(3,251)}=18.301, \mathrm{p}<0.01\right)$.

Tablo 6. Regresyon Modeli

\begin{tabular}{lccccccc}
\hline \multicolumn{1}{c}{ Değişken } & Katsay1 & Std. $\mathbf{H a t a}$ & $\boldsymbol{\beta}$ & $\boldsymbol{t}$ & $\boldsymbol{p}$ & $\boldsymbol{r}_{\text {ikili }}$ & $\boldsymbol{r}_{\text {kssmi }}$ \\
\hline \multicolumn{1}{c}{ Sabit } & 188,815 & 1,449 & & 130,352 &, 000 & & \\
Zpuanı(OMYT) & 11,181 & 1,622 &, 395 & 6,892 &, 000 &, 395 &, 399 \\
Zpuanı(gno) & 3,690 & 1,455 &, 146 & 2,536 &, 012 &, 156 &, 158 \\
Etkileşim &,- 898 & 1,534 &,- 034 &,- 585 &, 559 &,- 018 &,- 037 \\
\hline
\end{tabular}

Tablo 6 incelendiğinde UY ile OMYT arasında orta düzeyde pozitif $\left(\mathrm{r}_{\mathrm{ikili}}=0.395\right)$ bir ilişkinin olduğu, diğer değişkenler kontrol edildiğinde bu ilişkinin değişmediği $\left(\mathfrak{r}_{\mathrm{ksmm}}=0.399\right)$ görülmektedir. Genel not ortalaması ve UY arasında ise çok düşük düzeyde negatif ( $\left.r_{i k i l i}=-0.018\right)$ bir ilişskinin olduğu ve diğer değişkenler kontrol edildiğinde bu ilişkinin miktarının çok az yükseldiği $\left(\mathrm{r}_{\mathrm{k} \text { ksmi }}=0.037\right)$ görülmektedir. UY ve öğretmenlik mesleğine yönelik tutum ile genel not ortalamasının etkileşimi arasında düşük düzeyde pozitif $\left(\mathrm{r}_{\mathrm{ikili}}=0.156\right)$ bir ilişkinin olduğu, diğer değişkenler kontrol edildiğinde bu ilişkinin değişmediği $\left(\mathrm{r}_{\mathrm{kssmi}}=0.158\right)$ görülmektedir. 
Genel not ortalamasının, üniversite yaşamı üzerinde tek başına anlamlı bir etkisi yoktur. Ancak öğretmenlik mesleğine yönelik tutum ile genel not ortalamasının etkileşimi üniversite yaşamının anlamlı yordayıcısıdır. Bu durum genel not ortalamasının, üniversite yaşamı ile öğretmenlik mesleğine yönelik tutum arasındaki ilişkide düzenleyici değişken olduğunu göstermektedir. Bu duruma ek kanıt elde etmek amaciyla genel not ortalamasına göre oluşturulan alt gruplarda ilişkiler incelenmiştir. Genel not ortalaması 2-2.5 arasında olanların öğretmenlik mesleğine yönelik tutumları ile üniversite yaşamları arasında pozitif yönde yüksek düzeyde istatistiksel olarak anlamlı bir ilişki vardır ( $\mathrm{r}=0.786, \mathrm{p}=0.036, \mathrm{~N}=7)$. Genel not ortalaması 3.5-4.0 arasında olanların öğretmenlik mesleğine yönelik tutumlan ile üniversite yaşamları arasında pozitif yönde orta düzeyde istatistiksel olarak anlamlı bir ilişki vardır $(r=0.436, p=0.009, N=35)$.

\section{Tartışma, Sonuç ve Öneriler}

Bu çalışmada üniversite ve öğretmenlikle ilişkili değişkenler arasındaki ilişkiler ile aracı ve düzenleyici etkilerin belirlenmesi amaçlanmıştır. Bu doğrultuda, çalışma grubundan elde edilen veriler ile yapılan analizler doğrultusunda ulaşılan sonuçlar bu bölümde sunulmuştur.

Öğretmen adaylarının öğretmenlik mesleğine yönelik tutumları ile mesleki kayg1 arasında negatif yönde orta düzeyde istatistiksel olarak anlamlı bir ilişki vardır. Tümerdem (2007), Doğan ve Çoban (2009) ve Dadandı, Kalyon ve Yazıcı (2016) OMYT ile MK arasında negatif yönde düşük düzeyde ilişki bulurken, Kalemoğlu, Erbaş ve Ünlü (2014) ile Serin, Güneş ve Değirmenci (2015) bu çalışmaya benzer şekilde orta düzeyde negatif yönde anlamlı bir ilişki bulmuştur.

Öğretmen adaylarının okula yönelik tutumları ile mesleki kaygıları arasında negatif yönde düşük düzeyde istatistiksel olarak anlamlı bir ilişki vardır. DeVaney (2010), Finney ve Schraw (2003) ve Hussain (2011)'in çalşmaları da bu bulguya paralel bir biçimde MK ile OYT arasında negatif yönde bir ilişki olduğunu göstermektedir. Kalemoğlu, Erbaş ve Ünlü (2014) yaptıkları çalışmada mesleki kaygı düşerken okula yönelik tutumun arttığını raporlamıştır.

Üniversite yaşamı, üniversite öğrencilerinin akademik ve sosyal anlamda üniversitedeki diğer kişilerle uyumlu ve başarılı olmasını gerektirir (Kaba ve Keklik, 2016). Sağlıklı bir üniversite yaşamı için öğrencilerin kendisine ve üniversite yaşamına dair olumlu duygular ile dişsal destek ve imkanlara yeterli düzeyde sahip olması gerekir (Erol, 2016). Üniversite yaşamı öğrenciler için şehir, ortam, okul vb. açılardan yeni ve farklı olduğundan, uyum süreci gerektirir (Bülbül ve Acar-Güvendir, 2014). Olumlu duygu ve davranışlar kişiyi güçlü hissettirir ve uyumu kolaylaştırırken olumsuz duygu ve davranışlar ise uyum gücünü azaltır (Erdoğan, Şanlı ve Şimşek-Bekir, 2005). Ek olarak Okula yönelik tutum ile olumlu ve olumsuz duygular arasında orta düzeyde istatistiksel olarak anlamlı ilişkiler vardır. Duygular ve motivasyon okula yönelik tutumun anlamlı yordayıcılarıdır. (Moè, Pazzaglia, Tressoldi ve Toso, 2009). Öz-düzenleme, motivasyon ve bilişsel özellikleri ortaya çıkardığı için akademik ortamlardaki olumlu duygular oldukça önemlidir. Akademik ortamlardaki olumlu duygular okula yönelik tutumu önemli düzeyde etkilemektedir ve okula yönelik tutum konusundaki özgüven ile motivasyon arasındaki ilişkinin önemli bir aracısıdır (Pekrun, Goetz, Titz ve Perry, 2002; Goetz, Frenzel, Hall ve Pekrun, 2008). Bu çalışmada elde edilen verilerde, öğretmen adaylarının öğretmenlik mesleğine yönelik tutumları ile üniversite yaşamları arasında, öğretmenlik mesleğine yönelik tutumları ile okula yönelik tutumları arasında, okula yönelik tutumları ile üniversite yaşamları arasında pozitif yönde orta düzeyde, mesleki kayg1 ve üniversite yaşamları arasında ise negatif yönde orta düzeyde istatistiksel olarak anlamlı bir ilişki vardır. Üniversite yaşamı ile öğretmenlik mesleğine yönelik tutum arasındaki ilişkide hem mesleki kaygının hem de okula yönelik tutumun kısmen aracı olduğu bulunmuştur.

Erteleme, yaygın bir öz-denetimsel başarısızlıktır (Aremu, Williams ve Adesina, 2011) ve güdülenme kaynaklı bir sorundur (Watson, 2001). Dışsal güdülenme ile erteleme davranışı arasında pozitif bir ilişki vardır (Lekich, 2006). Bu çalışmada öğretmen adaylarının öğretmenlik mesleğine yönelik tutumları ile genel erteleme davranışları arasında negatif yönde orta düzeyde istatistiksel olarak anlamlı bir ilişki bulunmuştur. Kutlu, Gökdere ve Çakır (2015) yaptıkları çalışmada bu çalışma ile paralel olarak OMYT ile GEO arasında negatif yönde orta düzeyde ilişki olduğunu bulgulamışır. Çalışmada öğretmen adaylarının erteleme davranışlarının azaltılması ve mesleğe yönelik tutumlarının arttırılması için sosyal beceri kazandırmaya yönelik grup çalışmalarının düzenlenmesi önerilmiştir. Ek olarak bu çalışmada elde edilen verilerde, öğretmen adaylarının okula yönelik tutumları ile genel erteleme davranışları arasında negatif yönde düşük düzeyde, genel erteleme davranışları ile üniversite yaşamları arasında negatif yönde orta düzeyde, mesleki kaygıları ile genel erteleme davranışları arasında ise pozitif yönde düşük düzeyde istatistiksel olarak anlamlı 
bir ilişki vardır. Genel erteleme, öğretmenlik mesleğine yönelik tutum ile üniversite yaşamı arasındaki ilişkide kısmen aracıdır.

Öğrencilerin genel not ortalaması üniversite yaşam kalitesine dikkate değer oranda etki etmektedir (Maidinsah, Sari, Hamid, Ibrahim ve Shaadan, 2012). Ayrıca genel not ortalaması yüksek olan öğrencilerin öğretmenlik mesleğine yönelik tutumlarının düşük olanlardan anlamlı bir şekilde daha yüksek olduğu raporlanan çalışmalar bulunmaktadır (Abbasoğlu ve Öncü, 2013; Cinpolat, Alıncak ve Abakay, 2016). Zembat, Akşın-Yavuz, Tunçelı ve Yılmaz (2018) tarafından yapılan çalışmada da öğretmenlik mesleğine yönelik tutum ile genel not ortalaması arasında yüksek düzeyde anlamlı ilişki bulunmuştur. Moè, Pazzaglia, Tressoldi ve Toso (2009) yaptıkları çalışmada okula yönelik tutumun akademik başarıyı etkilediğini, okula yönelik tutumun motivasyon ve duyuşsal değişkenler ile akademik başarı arasındaki ilişkiye aracıllk ettiğini bulmuştur. Dahası, özgüven başarıyı doğrudan etkilerken, duygular ise motivasyonu içeren ilişkilere aracılık etmektedir. Olumsuz duygular ve olumlu duygular, okula yönelik tutumun aracıllk etmesi yoluyla akademik başarıyı etkiler. Okula karşı tutum ve akademik başarı arasındaki ilişki tek başına önemli değildir, ancak duygular, motivasyon ve öğrencilerin okula karşı tutumları arasında çok ve güçlü ilişskiler varken, bu faktörler ve akademik başarı arasındaki ilişki daha düşüktür. Öğrenciler okulda refah (iyi oluş) yaşayabilir, daha olumlu ve daha az olumsuz duygular hissedebilirse, daha yüksek akademik başarıya ulaşmadan etkili motivasyonlara sahip olabilirler. Okulda iyi hissetmek daha çok nesnel sonuçlara veya akademik notlara bağlı olarak yaşanan duygu ve motivasyonlara bağlı gibi görünmektedir. Bu çalısmada elde edilen verilerde, öğrencilerin öğretmenlik mesleğine yönelik tutumları ile üniversite yaşamları arasındaki ilişkide genel not ortalamasının düzenleyici etkisi olduğu bulunmuştur. Öğretmenlik mesleğine yönelik tutum ile üniversite yaşamları arasındaki ilişki; genel not ortalaması düşük olanlarda yüksek düzeydeyken, genel not ortalaması yüksek olanlarda orta düzeydedir. Ek olarak öğrencilerin öğretmenlik mesleğine yönelik tutumları ile üniversite yaşamları arasındaki ilişkide mesleği isteyerek seçmenin düzenleyici etkisi vardır. Öğretmenlik mesleğine yönelik tutum ile üniversite yaşamları arasındaki ilişki; mesleği isteyerek seçenlerde orta düzeydeyken, mesleği isteyerek seçmeyenlerde ilişki yoktur.

\section{Etik Beyan}

"Üniversite ve Öğretmenlikle İlişkili Değ̈̆skenler Arasindaki İliskide Aracı ve Düzenleyici Etkije Sabip Değ̈iskeenlerin Belirlenmesi” başlıklı çalısmanın yazım sürecinde bilimsel kurallara, etik ve alıntı kurallarına uyulmuş; toplanan veriler üzerinde herhangi bir tahrifat yapılmamış ve bu çalısma herhangi başka bir akademik yayın ortamına değerlendirme için gönderilmemiştir. Etik kurulu izni, proje yürütücüsünün talebi üzerine, Giresun Üniversitesi'nden Bilimsel Araştırma ve Yayın Etiği Kurulu'nun 17.01.2018 tarihli 44079388-14 sayılı toplantısında 2018-14/3 sayılı kararı ile onaylanmıştır.

\section{Teşekkür}

Bu çalışma Giresun Üniversitesi'nde çalışmanın ilk yazarı yürütücülüğünde tamamlanan EĞT-BAP-A230218-54 başlıklı Bilimsel Araştırma Projesi’nden üretilmiştir. Katkıları için Giresun Üniversitesi Bilimsel Araştırma Projeleri Koordinasyon Birimi’ne teşekkür ederiz.

\section{Kaynakça}

Abbasoğlu, E. ve Öncü, E. (2013). Beden eğitimi öğretmen adaylarının benlik sayg1ları ve öğretmenlik mesleğine yönelik tutumları. Ahi Evran Üniversitesi Krrşehir Eğitim Fakültesi Dergisi (KEFAD), 14(2), 407-425.

Aladağ, M., Kağnıc1, Y., Tuna, E. ve Tezer, E. (2003). Üniversite yaşamı ölçeği: Ölçek geliştirme ve yapı geçerliği üzerine bir çalışma. Türk Psikolojik Danısma ve Rebberlik Dergisi, 2(20), 41-47.

Aremu, A. O., Williams, T. M. ve Adesina, F. T. (2011). Influence of academic procrastination and personality types on academic achievement and efficacy of in-school adolescents in Ibadan. Ife psychologia, 19(1), 93-113.

Avcı Vardar, E. (2019). Arac ve düzenleyici etkilerin modellenmesi (Master's Thesis). Sağlık Bilimleri Enstitüsü.

Baron, R. M. ve Kenny, D. A. (1986). The moderator-mediator variable distinction in social psychological research: conceptual, strategic, and statistical considerations. Journal of Personality and Social Psychology, 51, 1173-1182.

Bülbül, T. ve Acar-Güvendir, M. (2014). Üniversite birinci sınıf öğrencilerinin yükseköğretim yaşamına uyum düzeylerinin incelenmesi. Eğitim Bilimleri Araștırmalar Dergisi, 4(1), 397-418.

Büyüköztürk, Ş. (2014). Sosyal bilimler için veri analiži el kitabı. Ankara: Pegem.

Cabı, E. ve Yalçınalp, S. (2013). Öğretmen adaylarına yönelik mesleki kayg1 ölçeği: geçerlik ve güvenirlik çalışması. Hacettepe Üniversitesi Ë̆itim Fakültesi Dergisi, 44, 85-96.

Cinpolat, T., Alıncak, F. ve Abakay, U. (2016). Beden eğitimi ve spor yüksekokulu öğrencilerinin öğretmenlik mesleğine yönelik tutumlarının incelenmesi. Gaziantep Üniversitesi Spor Bilimleri Dergisi, 1(1), 38-47. 
Çakıcı, D. Ç. (2003). Lise ve üniversite öğrencilerinde genel ve akademik erteleme davranışının incelenmesi (Yüksek Lisans Tezi). Ankara Üniversitesi Eğitim Bilimleri Fakültesi, Ankara.

Çokluk, Ö. Şekercioğlu, G. ve Büyüköztürk, Ş. (2010). Sosyal bilimler için çok değişkenli istatistik: SPSS ve lisrel uygulamalar. Ankara: PegemA.

Dadand1, İ., Kalyon, A. ve Yazıc1, H. (2016) Eğitim fakültesinde öğrenim gören ve pedagojik formasyon eğitimi alan öğretmen adaylarının öz-yeterlik inançları, kayg1 düzeyleri ve öğretmenlik mesleğine karşı tutumları. Bayburt Eğitim Fakültesi Dergisi, 11(1), 253-269.

Demir, F. ve Kösterelioğlu, İ. (2015). Öğretmen adaylarının akademik erteleme eğilimlerinin incelenmesi. Journal of International Social Research, 8(39).

Doğan, T. ve Çoban, A. E. (2009). Ĕ̆itim fakültesi öğrencilerinin öğretmenlik mesleğine yönelik tutumları ile kayg1 düzeyleri arasındaki ilişkinin incelenmesi. Ë̆itim ve Bilim, 34(153).

Erdoğan, S., Şanlı, H. S. ve Şimşek-Bekir, H. (2005). Gazi üniversitesi, eğitim fakültesi öğrencilerinin üniversite yaşamına uyum durumları. Kastamonu Ë̆itim Dergisi, 479.

Erol, M. (2016). Genç yetişkinliğin öncesinde olan ergenlerin yaşam doyumu: "Utangaçlık" ve “öz yeterlik algısı"nın rolü. Türk Psikiyatri Dergisi. doi: 10.5080/u13563.

Ferrari, J. R., Johnson, J. L. ve McCown, W. G. (1995). Procrastination and task avoidance: theory, research, and treatment. New York: Plenum, now Springer.

Goetz, T., Frenzel, A. C., Hall, N. C. ve Pekrun, R. (2008). Antecedents of academic emotions: Testing the internal/external frame of reference model for academic enjoyment. Contemporary Educational Psychology, 33, 9-33.

Gülleroğlu, H. D. (2008). Okula ilişkin tutum ölçeği. Eğitim Bilimleri ve Uygulama Dergisi, 7(13), 77-86

Kaba, İ. ve Keklik, İ. (2016). Öğrencilerin üniversite yaşamına uyumlarında psikolojik dayanıklılık ve psikolojik belirtiler. The Journal of Educational Research, 2(2), 98-113.

Kalemoğlu, V. Y., Erbaş, M. K. ve Ünlü H. (2014). Beden eğitimi öğretmen adaylarının mesleki kayg1 düzeylerinin öğretmenlik mesleğine yönelik tutumlarını yordama gücü. SPORMETRE Beden Eğitimi ve Spor Bilimleri Dergisi, 12(2), 113-123.

Kline, R. B. (2005). Principles and practice of structural equation modelling. New York, NY: Guilford.

Kutlu, N., Gökdere, M. ve Çakır, R. (2015). Öğretmen adaylarının akademik erteleme davranışı ile öğretmenlik mesleğine ilişkin tutumlarının karşılaştırmalı. Kastamonu Ë̆itim Dergisi, 23(3), 1311-1330.

Maidinsah, H., Sari M. M., Hamid K. A., Ibrahim, N. A. ve Shaadan, N. (2012). Quality of university life (QUL): A case study of Malay students. Discovering Mathematics, 34(2), 15-24.

Moè, A., Pazzaglia, F., Tressoldi, P. ve Toso, C. (2009). Attitude towards school, motivation, emotions and academic achievement. Educational Psychology: Cognition and Learning, Individual Differences and Motivation, 259-273.

Pajares, M. (1992). Teachers' beliefs and educational research: Cleaning up a messy construct. Review of Educational Research, 62(3), 307-332.

Pantić, N. ve Florian, L. (2015). Developing teachers as agents of inclusion and social justice. Education Inquiry, 6(3), 333-351.

Pekrun, R., Goetz, T., Titz, W. ve Perry R. P. (2002). Academic emotions in students' selfregulated learning and achievement: A program of qualitative and quantitative research. Educational Psychologist, 37, 91-105.

Poulou, M. (2007). Student-teachers' concerns about teaching practice. European Journal of Teacher Education, $30(1), 91$ 110.

Richardson, V. (1996). The role of attitudes and beliefs in learning to teach. Handbook of research on teacher education, 2(102-119).

Richardson, V. (Edt.). (1994). Teacher change and the staff development process: A case in reading instruction. New York: Teachers College Press.

Rozental, A. ve Carlbring, P. (2013). Internet-based cognitive behavior therapy for procrastination: study protocol for a randomized controlled trial. Journal of Medical Internet Research, 15(11), 27.

Serin, M. K., Güneş, A. M. ve Değirmenci, H. (2015). Sınıf öğretmenliği bölümü öğrencilerinin öğretmenlik mesleğine yönelik tutumları ile mesleğe yönelik kayg1 düzeyleri arasındaki ilişki. Cumburiyet Uluslararası Ĕgitim Dergisi, 4(1), 21-34.

Steel, P. ve Ferrari, J. (2013). Sex, education and procrastination: an epidemiological study of procrastinators' characteristics from a global sample. European Journal of Personality, 27(1), 51-58.

Schubert Walker, L. J. ve Stewart, D. W. (2000). Overcoming the powerlessness of procrastination. Guidance \& Counseling, 16(1), 39-43.

Tabachnick, B. G. ve Fidell, L. S. (2001). Using Multivariate Statistics (5 $5^{\text {th }}$ Edition) USA: Pearson.

Tümerdem R. (2007): Dicle üniversitesi eğitim fakültesi ve fen-edebiyat fakültesi kimya son sinıf öğrencilerinin kaygılarını etkileyen etmenler. Elektronik Sosyal Bilimler Dergisi, 6(20), 32-45.

Üstüner, M. (2006). Öğretmenlik mesleğine yönelik tutum ölçeğinin geçerlik ve güvenirlik çalışması. Kuram ve Uygulamada Ë̈itim Yönetimi, 12(45), 109-127.

Watson (2001). Procrastination and the five-factor model: a facet level analysis. Personality and Individual Differences, 30 , 149-159.

Zhang, Q., Luo, Y., Zhang, X. ve Wang, Y. (2018). The relationship among school safety, school satisfaction, and students' cigarette smoking: Based on a multilevel mediation model. Children and Youth Services Review, 88, 96102. 
Zembat, R., Akşın-Yavuz, E., Tunçelı, H. İ. ve Yılmaz, H. (2018). Öğretmenlik mesleğine yönelik tutum ile akademik motivasyon ve başarı arasındaki ilişkinin incelenmesi. Journal of Theoretical Educational Science, 11(4), 789-808.

\section{EXTENDED ABSTRACT}

The relationship between the two variables may depend not only on the individual's score for these two variables, but also on different variables that affect these variables. From this point of view, it is important for the steps to be taken to increase student achievement whether the relationships between the variables associated with university and teaching are caused only by these variables or different variables associated with these variables. This study is a correlational study. The aim of this study is to determine the relations between university and teaching variables and mediator and moderator effects. For this basic purpose, answers to the following questions were sought:

1. What are the relationships between students' attitudes towards school, attitudes towards teaching profession, professional anxiety, university lives and general procrastination behaviors?

2. Do the professional anxieties, attitudes towards school and general procrastination behaviors have a mediator effect on the relationship between students' attitudes towards teaching profession and university life?

3. Do overall grade average and choosing the profession by willingly have a mediator effect on the relationship between students' attitudes towards teaching profession and university life?

The study group of the research consists of 268 prospective teachers studying in different departments of a faculty of education and at different grade levels. Within the scope of the study, the Attitude Scale for Teaching Profession, Attitude Scale for School, Occupational Anxiety Scale, University Life Scale, and General Procrastination Scale were used as a data collection tool with a questionnaire created by researchers. Within the scope of the study, first of all, missing values, extreme values, normality of total scores, multicollinearity problem were examined. The mediator effect was tested by path analysis and the moderator effect was tested by multiple linear regression analysis. For the variable to be the mediator, the independent variable must first affect the mediator variable, and the mediator variable must affect the dependent variable. The moderator variable affects the strength or direction of the relationship between the dependent and independent variables (Baron, \& Kenny, 1986). The mediation model aims to reveal the indirect and direct effects of the dependent variable. It is a frequently used statistical technique in behavioral sciences, especially because it can reveal indirect effects. Thanks to this statistical technique, the maximum effect of the independent variable on the dependent variable can be examined, as well as the productivity effect of the intermediary variables (Baron, \& Kenny, 1986). Before the models were installed, the measurement model was tested with confirmatory factor analysis for each measurement tool. Relationships were calculated with Pearson correlation coefficients in order to determine the relationships between students' attitudes towards teaching profession (OMYT), attitudes towards school (OYT), professional anxiety (MK), general procrastination behaviors (GEO) and university life (UY). First of all, the model was tested without adding the mediator variable to the model and the path diagram (standardized values) of the model was presented. Then, the moderator was added to the model and the model was tested again and the path diagram (standardized values) related to the model, which was the intermediate variable, was presented. Then the fit index values of the mediation model were evaluated. When the validity evidences obtained from the analysis (fit index values, standardized loads, explained variance, error variance and $t$ values) were evaluated together, the models examined were compatible. Relationships were examined separately in subgroups to obtain additional evidence for moderator effects. In line with the analyzes made with the data obtained from the study group: There is a moderately positive statistically significant relationship between the attitudes of teacher candidates towards the teaching profession and their attitudes towards school and university life, and moderately negative statistically significant relationship between their attitudes towards teaching profession and their professional anxiety and general procrastination behaviors. There is a low statistically significant relationship between teacher candidates' attitudes towards school and their university lives at a positive level, and attitudes towards school with their professional anxiety and general procrastination behaviors at a negative level. There is a statistically significant relationship between teacher candidates' professional anxieties and general procrastination behaviors at a low level positively and negatively between university lives. There is a moderately statistically significant relationship between the general procrastination behavior of prospective teachers and university life. Professional anxiety is partially mediated in the relationship between attitude 
UYUMAZ, SARI, UYUMAZ ve YILMAZ

Üniversite ve Öğretmenlikle İlişkili Değgişkenler Arasındaki İlişkide Aracı ve Düzenleyici Etkiye Sahip Değgşkenlerin Belirlenmesi

towards teaching profession and university life. The attitude towards school is partially mediated in the relationship between attitude towards teaching profession and university life. General procrastination is partially mediated in the relationship between attitude towards teaching profession and university life. The overall grade average has a moderator effect on the relationship between students' attitudes towards teaching profession and university life. In the relationship between students' attitudes towards teaching profession and university life, choosing the profession willingly has a moderator effect. 